\title{
Mutations in the p53 and SCID genes cooperate in tumorigenesis
}

\author{
Mariana Nacht, ${ }^{1}$ Andreas Strasser, ${ }^{2}$ Yvonne R. Chan, ${ }^{3,4}$ Alan W. Harris, ${ }^{2}$ Mark Schlissel, ${ }^{5}$ Roderick \\ T. Bronson, ${ }^{6}$ and Tyler Jacks ${ }^{1,7}$ \\ ${ }^{1}$ Howard Hughes Medical Institute, Center for Cancer Research, ${ }^{3}$ Department of Biology, Massachusetts Institute of \\ Technology, Cambridge, Massachusetts 02139 USA; $^{2}$ The Walter and Eliza Hall Institute of Medical Research, Royal \\ Melbourne Hospital, Victoria 3050, Australia; ${ }^{5}$ Departments of Medicine and Molecular Biology and Genetics, John Hopkins \\ University School of Medicine, Baltimore, Maryland 21205 USA; $^{6}$ Department of Pathology, Tufts University Schools of \\ Medicine and Veterinary Medicine, Boston, Massachusetts 02111 USA
}

DNA damage can cause mutations that contribute to cellular transformation and tumorigenesis. The p53 tumor suppressor acts to protect the organism from DNA damage by inducing either $G_{1}$ arrest to facilitate DNA repair or by activating physiological cell death (apoptosis). Consistent with this critical function of p53, mice lacking p53 are predisposed to developing tumors, particularly lymphoma. The severe combined immune deficiency (scid) locus encodes the catalytic subunit of DNA protein kinase (DNA-PKcs), a protein complex that has a role in the cellular response to DNA damage. Cells from scid mice are hypersensitive to radiation and scid lymphocytes fail to develop from precursors because they are unable to properly join DNA-coding ends during antigen receptor gene rearrangement. We examined the combined effect of loss of p53 and loss of DNA-PKcs on lymphocyte development and tumorigenesis by generating $\mathrm{p}^{-1-}$ scid mice. Our data demonstrate that loss of $\mathbf{p} 53$ promotes $\mathrm{T}$-cell development in scid mice but does not noticeably affect $B$ lymphopoiesis. Moreover, scid cells are able to induce $p 53$ protein expression and activate $G_{1}$ arrest or apoptosis in response to ionizing radiation, indicating that DNA-PKcs is not essential for these responses to DNA damage. Furthermore, $\mathrm{p} 53^{-1-}$ scid double mutant mice develop lymphoma earlier than $\mathrm{p} 53^{-1-}$ littermates, demonstrating that loss of these two genes can cooperate in tumorigenesis. Collectively, these results provide evidence for an unsuspected role of p53 as a checkpoint regulator in early $T$-cell development and demonstrate that loss of an additional component of the cellular response to DNA damage can cooperate with loss of p53 in lymphomagenesis.

[Key Words: p53; SCID; tumorigenesis; T-cell development]

Received March 8, 1996; revised version accepted July 3, 1996.

DNA damage, such as double-strand breaks, may cause mutations that activate oncogenes or inactivate tumor suppressor genes, resulting in cellular transformation and tumorigenesis. DNA repair is facilitated by cell cycle arrest at the $\mathrm{G}_{1} / \mathrm{S}$ checkpoint, to prevent replication of mutated DNA, and at the $G_{2} / M$ checkpoint to prevent transmission of damaged chromosomes. Alternatively, apoptotic cell death may be initiated to eliminate the damaged cell (for review, see Lane 1993). Mutations that cause deficiency in one or both of these functions cause hypersensitivity to agents that induce double-strand DNA breaks and predispose individuals to developing cancer (for review, see Weaver 1995).

Mice with a homozygous mutation at the severe combined immune deficient (scid) locus have a defect in lymphocyte development attributable to an inability to successfully join coding ends of DNA during $V(D) I$ recombination of antigen receptor genes (Bosma et al. 1983;

\footnotetext{
${ }^{4}$ Present address: Harvard Medical School, Boston, Massachusetts 02115. ${ }^{7}$ Corresponding author.
}

Schuler et al. 1986). scid thymocytes are unable to rearrange T-cell receptor (TCR) $\beta$ genes functionally and therefore fail to pass the first checkpoint in T-cell development that requires surface expression of TCR $\beta$ in conjunction with the surrogate TCR $\alpha$ chain gp33 and the CD3 complex (for review, see Godfrey and Zlotnik 1993). $T$-cell development in scid mice therefore arrests at the transition from the $\mathrm{CD} 4{ }^{-} \mathrm{CD} 8^{-} \mathrm{CD} 25^{+} \mathrm{CD} 44^{-}$to the $\mathrm{CD} 4{ }^{-} \mathrm{CD} 8{ }^{-} \mathrm{CD} 25^{-} \mathrm{CD} 44^{-}$stage from which $\mathrm{CD} 3^{+}$ $\mathrm{CD} 4{ }^{+} \mathrm{CD} 8{ }^{+}$cells arise spontaneously. Similarly, B lymphopoiesis is arrested in scid mice at the checkpoint that requires expression of immunoglobulin heavy $(\mathrm{IgH})$ chain together with $\lambda 5, \mathrm{v}$-preB, mb-1, and B29 proteins (for review, see Rolink and Melchers 1991). As a consequence of these defects, scid lymphoid tissues are hypoplastic. scid thymus, spleen, and lymph nodes contain $\sim 1 \%$ of the normal number of $B$ and $T$ lymphocytes (Strasser et al. 1994a).

The scid mutation also results in a generalized defect in DNA double-strand break repair because scid myeloid cells and fibroblasts are hypersensitive to ionizing radi- 
ation (Fulop and Phillips 1990; Biedermann et al. 1991). Recently, the scid gene product was identified as $\mathrm{p} 450$, the catalytic subunit of the DNA-dependent serine/threonine protein kinase (DNA-PK) that also includes the DNA-binding protein $\mathrm{Ku}$, composed of two subunits, Ku70 and Ku80 (Blunt et al. 1995; Kirchgessner et al. 1995; Lees-Miller et al. 1995). Cells lacking either p450 or $\mathrm{Ku}$ activity are hypersensitive to DNA damaging agents, suggesting that DNA-PK has an important role in the recognition and repair of DNA damage (for review, see Weaver 1995). Interestingly, this complex is able to phosphorylate the p53 tumor suppressor protein in vitro, and it has been suggested that such phosphorylation occurs in vivo to stabilize the $\mathrm{p} 53$ protein in response to DNA damage (Gottlieb and Jackson 1994).

Several studies provide evidence that p53 has an important role in protecting cells against DNA damage. The $p 53$ gene is found mutated in many human cancers (Hollstein et al. 1991; Levine et al. 1991) and is required for radiation-induced $G_{1}$ cell cycle arrest (Kastan et al. 1992). p53 is also a crucial upstream regulator of apoptosis. Thymocytes and B cells from p53-deficient mice are dramatically resistant to the induction of apoptosis by DNA damage, but retain normal sensitivity to phorbol esters, glucocorticoids, and calcium ionophore (Clarke et al. 1993; Lowe et al. 1993; Strasser et al. 1994b). Presumably as a consequence of loss of the cell cycle checkpoint regulation and cell death control, p53deficient mice have a markedly increased susceptibility to developing malignant lymphoma (Donehower et al. 1992; Jacks et al. 1994).

Because scid lymphocytes have a faulty DNA repair mechanism that results in incomplete $V(D) /$ recombination, we examined whether the scid mutation could cooperate with loss of p53 function to accelerate lymphomagenesis. By intercrossing $\mathrm{p} 53^{-1-}$ mice and scid mice, we found that $\mathrm{p} 53^{-1-}$ scid double mutant animals had a surprising partial rescue of $\mathrm{T}$ but not $\mathrm{B}$ cell development and, in comparison with control p53 $3^{-1-}$ littermates, an accelerated rate of developing lymphoma. We also found that scid cells are able to induce and activate p53-responsive signaling pathways following DNA damage. In summary, our results reveal a role for p53 in a T-cell developmental checkpoint unknown previously and demonstrate for the first time that mutations in independent regulators of the cellular response to DNA damage can cooperate in lymphomagenesis.

\section{Results}

p53-1- scid mice show a partial rescue of T-cell, but not B-cell, development

Mice homozygous for the scid mutation are unable to rearrange antigen receptor genes successfully, leading to an arrest in lymphocyte development at the $\mathrm{CD} 4{ }^{-} \mathrm{CD} 8{ }^{-} \mathrm{CD} 25^{+} \mathrm{CD} 44^{-}$pre-T-cell stage and the $\mathrm{B} 220^{+} \mathrm{CD}_{43}{ }^{+}$pro-B-cell stage (Bosma et al. 1983; Schuler et al. 1986; Godfrey and Zlotnick 1993). These animals also have a general defect in DNA damage repair (Fulop and Phillips 1990; Biedermann et al. 1991). The p53 tumor suppressor has an essential role in the cellular response to DNA damage by inducing either $G_{1}$ cell cycle arrest, allowing the cell time to repair the damage (Kastan et al. 1992), or by activating apoptosis to eliminate the damaged cells (Clarke et al. 1993; Lowe et al. 1993). To examine the combined impact of loss of p53 and defective $V(D) I$ antigen receptor gene recombination on lymphocyte differentiation and neoplastic transformation, we introduced a $p 53$-null allele into scid mice by genetic crosses between the mutant strains. Double mutant $\mathrm{p} 53^{-1-}$ scid animals were created on two different genetic backgrounds-C.B.-17-C57BL/6-129/Sv and C.B-17-C57BL/ 6 (see Materials and methods)-and experiments with animals from both cohorts produced similar results.

To investigate the effect of loss of p53 on lymphocyte differentiation in mutant scid mice we isolated thymocytes, bone marrow, spleen, and lymph node cells from 4- to 6-week-old, apparently healthy (not tumor burdened), double mutant $\mathrm{p} 53^{-1-}$ scid mice, enumerated them, and characterized them by immunofluorescent staining with cell surface marker-specific monoclonal antibodies and flow cytometric analysis.

Thymi from $\mathrm{p}^{2} 3^{-1-}$ scid mice contained 2- to 50-fold more lymphocytes than those from control $\mathrm{p} 53^{+/+}$scid and $\mathrm{p} 53^{+1-}$ scid littermates, although the total number of thymocytes varied greatly between individual animals. As reported previously, p53 ${ }^{-1-}$ mice are indistinguishable from controls with respect to thymus cellularity and subset distribution (Fig. 1A, Table 1; Lowe et al. 1993; Strasser et al. 1994b). Furthermore, as expected, T lymphopoiesis was arrested in $\mathrm{p} 53^{+1+}$ scid and $\mathrm{p} 53^{+1-}$ scid littermates at the $\mathrm{CD} 4{ }^{-} \mathrm{CD} 8{ }^{-} \mathrm{CD} 25^{+} \mathrm{CD} 44^{-}$stage (Fig. 1A; data not shown). In contrast, $\mathrm{p} 53^{-1-}$ scid thymi contained nearly wild-type portions of more mature, $\mathrm{CD} 4^{-} \mathrm{CD} 8{ }^{-} \mathrm{CD} 25^{-} \mathrm{CD} 44^{-}$and $\mathrm{CD} 4{ }^{+} \mathrm{CD} 8{ }^{+}$cells (Fig. 1A; data not shown). Recently, Bogue et al. (1996) also observed $\mathrm{CD} 4{ }^{+} \mathrm{CD} 8{ }^{+}$thymocytes in $\mathrm{p} 53-/-$ scid mice. The presence of these two differentiation stages was entirely responsible for the increased thymus cellularity and the three earlier thymocyte differentiation stages, $\mathrm{CD} 4^{-} \mathrm{CD} 8{ }^{-} \mathrm{CD} 25^{-} \mathrm{CD} 44^{+}, \mathrm{CD} 4^{-} \mathrm{CD} 8{ }^{-}$ $\mathrm{CD} 25^{+} \mathrm{CD} 44^{+}$, and $\mathrm{CD} 44^{-} \mathrm{CD} 8{ }^{-} \mathrm{CD} 25^{+} \mathrm{CD} 44^{-}$, were present in normal numbers (Table 1 ; data not shown). The $\mathrm{p} 53^{-1-}$ scid thymocytes were unable to proceed beyond the cortical CD4 ${ }^{+} \mathrm{CD} 8{ }^{+}$stage, because we could not detect any surface expression of TCR $\alpha \beta$, TCR $\gamma \delta$, or $\mathrm{CD} 3 \epsilon$ on double mutant thymocytes or any $\mathrm{T}$ cells in peripheral lymphoid organs (data not shown). These data demonstrate that loss of p53 function allows defective scid thymocytes to survive, proliferate, and progress in development beyond the checkpoint that normally requires TCR $\beta$ expression.

In contrast to our observations in thymocytes, loss of p53 did not relieve the developmental block in scid B lymphopoiesis. Detailed analysis of bone marrow leukocytes did not identify a difference in number or phenotype among B lineage cells from ${\mathrm{p} 53^{-1-}}$ scid and 

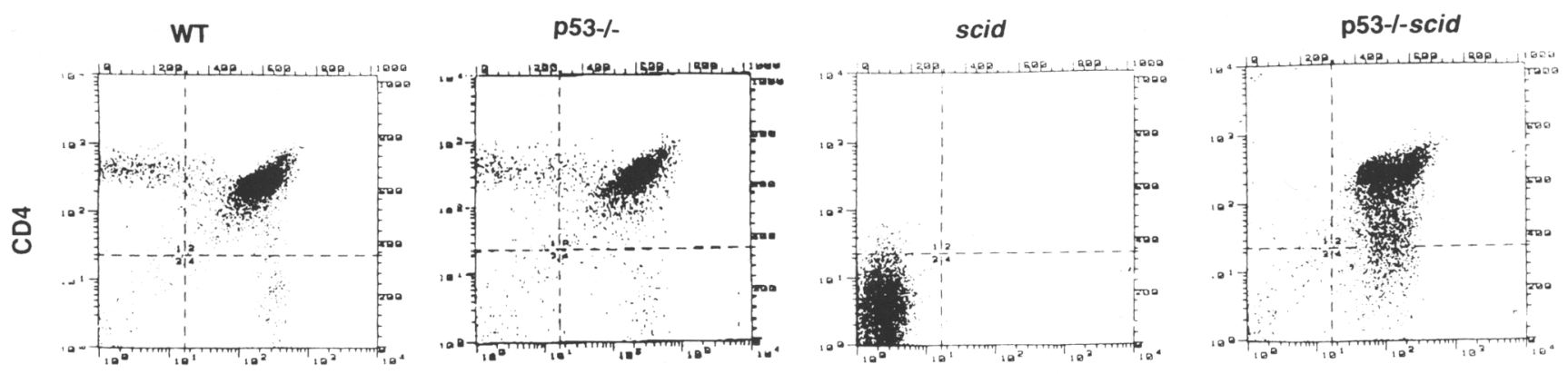

CD8

B
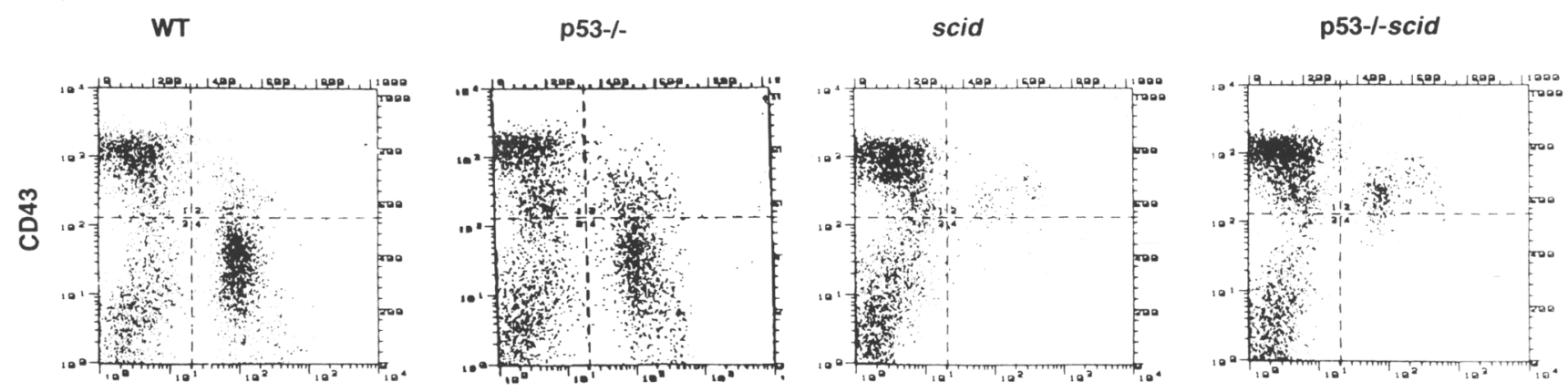

B220

Figure 1. Immunofluorescence staining and flow cytometric analysis of thymocytes and bone marrow cells from healthy 4- to 6-week-old p53-1- scid mice demonstrates a partial rescue of T-cell but not B-cell development. (A) Thymocytes from wild-type (WT), $\mathrm{p} 53^{-1-}\left(\mathrm{p} 53^{-1-}\right), \mathrm{p} 53^{+1+}$ scid $($ scid $)$, and $\mathrm{p} 53^{-1-}$ scid mice were stained with a PE-conjugated antibody to CD4 and a FITC-conjugated antibody to CD8. Wild-type and $\mathrm{p}^{-1-}$ cells are largely CD4 ${ }^{+} \mathrm{CD} 8 *$ (double positive; DP), scid cells are exclusively double negative $(\mathrm{DN})$, and $\mathrm{p} 53^{-1-}$ scid cells show an increase in the total number of DP cells. $(B)$ Bone-marrow cells from wild-type (WT), p53 ${ }^{-1-}$ (p53 $3^{-1-}$ ), p53 $3^{+1+}$ scid (scid), and $\mathrm{p} 53^{-1-}$ scid mice were stained with a biotinylated antibody to CD43 revealed by PE-streptavidin, and a FITC-conjugated antibody to B220. Wild-type and $\mathrm{p} 53^{-1-}$ bone marrow contain immature, $\mathrm{CD} 43^{+} \mathrm{B} 220^{+}$and $\mathrm{mature}$ $\mathrm{CD} 43^{-} \mathrm{B} 220^{+} \mathrm{B}$ lineage cells, whereas scid and $\mathrm{p} 53^{-1-}$ scid mice contain predominantly immature $\mathrm{CD} 43^{+} \mathrm{B} 220^{+}$cells.

$\mathrm{p} 53^{+1+}$ scid or $\mathrm{p} 53^{+1-}$ scid mice (Fig. $1 \mathrm{~B}_{\text {; data not }}$ shown). All of the $\mathrm{B} 220^{+}$cells were found to be $\mathrm{CD} 43^{+}$ (Fig. 1B) and contained populations of both $\mathrm{CD} 25^{+}$and CD25- cells (data not shown). In constrast, the majority of $\mathrm{B} 220^{+}$bone marrow cells from control and $\mathrm{p} 53^{-1-}$ mice were $\mathrm{CD} 43^{-}$. These results indicate that $\mathrm{p} 53^{-1-}$ scid $\mathrm{B}$ lineage cells are arrested at the pro-B/early pre-B stage of development, as described previously for those

Table 1. Lymphoid cells subsets in thymus and bone marrow

\begin{tabular}{|c|c|c|c|c|}
\hline & WT & $\mathrm{p} 53^{-/-}$ & scid & $\mathrm{p} 53^{-1-}$ scid \\
\hline Thymus cells (total) & $1.9 \pm 0.7 \times 10^{8}$ & $1.7 \pm 0.6 \times 10^{8}$ & $3.3 \pm 0.9 \times 10^{6}$ & $7.1 \times 10^{6}$ to $1 \times 10^{8}$ \\
\hline $\mathrm{CD}^{-} \mathrm{CD} 8^{-}$ & $5.7 \pm 1.9 \times 10^{6}$ & $3.7 \pm 0.7 \times 10^{6}$ & $2.9 \pm 0.8 \times 10^{6}$ & $2.3 \pm 0.8 \times 10^{6}$ \\
\hline $\mathrm{CD}^{+}{ }^{+} \mathrm{CD} 8^{+}$ & $1.7 \pm 0.6 \times 10^{8}$ & $1.5 \pm 0.6 \times 10^{8}$ & $<3 \times 10^{4}$ & $3.9 \times 10^{6}$ \\
\hline $\mathrm{CD}^{+}{ }^{+} \mathrm{CD} 8{ }^{-}$ & $1.7 \pm 0.6 \times 10^{7}$ & $1.3 \pm 0.2 \times 10^{7}$ & $<3 \times 10^{4}$ & $<3 \times 10^{4}$ \\
\hline $\mathrm{CD}^{-}{ }^{-} \mathrm{CD} 8^{+}$ & $6.1 \pm 3.7 \times 10^{6}$ & $4.8 \pm 1.1 \times 10^{6}$ & $<3 \times 10^{4}$ & $<3 \times 10^{4}$ \\
\hline BM cells (total) & $2.5 \pm 0.7 \times 10^{7}$ & $2.4 \pm 0.4 \times 10^{7}$ & $2.2 \pm 0.5 \times 10^{7}$ & $2.4 \pm 0.5 \times 10^{7}$ \\
\hline $\mathrm{B} 220^{+} \mathrm{slg}^{-}$ & $5.8 \pm 2.2 \times 10^{6}$ & $6.3 \pm 3.0 \times 10^{6}$ & $2.0 \pm 0.3 \times 10^{6}$ & $3.3 \pm 1.1 \times 10^{6}$ \\
\hline $\mathrm{B} 220^{+} \operatorname{slg}^{+}$ & $2.9 \pm 1.4 \times 10^{6}$ & $3.0 \pm 0.5 \times 10^{6}$ & $<3 \times 10^{4}$ & $<3 \times 10^{4}$ \\
\hline
\end{tabular}

Lymphoid cell subsets in thymus and bone marrow indicates that $\mathrm{p} 53^{-1-}$ scid mice have increased numbers of thymocytes which are $\mathrm{CD}^{+}{ }^{+} \mathrm{CD} 8{ }^{+}$. Thymocytes and BM cells were isolated from 3 to 5 mice of each genotype. Values shown are mean \pm s.D. 
from scid mice (for review, see Rolink and Melchers 1991). Collectively, these data provide evidence for an unsuspected difference in the molecular regulation of early B- and T- cell differentiation, perhaps attributable to the p53-dependent elimination of defective lymphoid progenitors that may occur in the T-cell, but not the B-cell, lineage.

\section{$C D 4^{+} C D 8^{+}$thymocytes in $p 53^{-1-}$ scid mice are polyclonal}

The observation that the double mutant animals had significantly increased thymus cellularity consisting predominantly of $\mathrm{CD} 4{ }^{+} \mathrm{CD} 8{ }^{+}$cells suggested that loss of p53 allowed immature thymocytes to progress further in development despite the absence of $\mathrm{TCR}_{\beta}$. However, it was also possible that the increased cellularity resulted from a clonal expansion of one or a few transformed cells. To examine this question further, we characterized the diversity of the coding joints of a TCR gene segment from DNA isolated from populations of double mutant thymocytes. Coding joints form inefficiently in scid thy- mocytes, and the rearrangements that have been characterized usually contain gross deletions at the joints (Lieber et al. 1988). DNA was extracted from thymi of fiveto six-week-old p53 $3^{-1-}$ scid mice, and the TCR $\mathrm{D}_{\beta}-\mathrm{J}_{\beta}$ joints were amplified by PCR using primers that recognize the $5^{\prime}$ end of the $D_{\beta}$ region and the $3^{\prime}$ end of the $\mathrm{J}_{\beta} 1.2$ segment. DNA from $\mathrm{p} 53^{-1-}$ scid mice yielded predominantly the unrearranged germ-line band of $\sim 1.2 \mathrm{~kb}$ and two faint bands of 350 and $500 \mathrm{bp}$, corresponding to rare rearrangements to the $\mathrm{J}_{\beta} 1.2$ and $\mathrm{J}_{\beta} 1.1$ segments, respectively (data not shown). The band corresponding to the $\mathrm{J}_{\beta} 1.1$ rearrangement was purified, reamplified by $\mathrm{PCR}$, and subcloned to create a library of $\mathrm{TCR}_{\beta}$ joints. These clones were sequenced and compared with published $\mathrm{TCR}_{\beta}$-region sequences to determine the nature of the joints (Table 2). This analysis revealed that $\mathrm{p} 53^{-1-}$ scid thymocytes contained a variety of largely nonproductive rearrangements, indicating that these cells were polyclonal. It is noteworthy that most of the joints from p $53^{-1-}$ scid mice, unlike those in scid thymocytes, did not show significant deletions at the coding ends. These data indicate that the absence of p53 allows a polyclonal population of defective scid thymocytes to

Table 2. Sequence analysis of $D_{\beta} t_{\beta}$ ioints in $p 53^{-1-}$ scid double mutant thymocytes

\begin{tabular}{|c|c|c|c|c|}
\hline Clone & Dß sequence & Dß-Jß $N$ region & Jß sequence & In frame \\
\hline Published & GGGACAGGGGGC & & CAAACACAGAAGTCTTCTITGGTAAAGGAACCAGACTCACAGTTGTAG & \\
\hline W1 & GGGACA & $\pi \mathrm{TG}$ & CAAACACAGAAGTCTTCTITGGTAAAGGAACCAGACTCACAGTTGTAG & + \\
\hline W2 & GGGACAGGGG & $T$ & GAAGTCTTCTTTGGTAAAGGAACCAGACTCACAGTTGTAG & - \\
\hline W5 & GGGACAGGGGG & G & GTCTTCTTTGGTAAAGGAACCAGACTCACAGTTGTAG & + \\
\hline D25-3 & GGGACAGGGGGC & CGC & CACAGAAGTCTTCTTTGGTAAAGGAACCAGACTCACAGTTGTAG & - \\
\hline D25-4 & GGGACAGGGG & TTCTTCC & TTGGTAAAGGAACCAGACTCACAGTTGTAG & - \\
\hline D25-5 & deleted $^{\star \star}$ & & ACAGAAGTCTTCTTTGGTAAAGGAACCAGACTCACAGTTGTAG & \\
\hline D25-7 & GGGACAGGGG & & GAAGTCTTCTTTGGTAAAGGAACCAGACTCACAGTTGTAG & - \\
\hline D25-8 & GGGACAGGGGGC & G & GTCTTCTTTGGTAAAGGAACCAGACTCACAGTTGTAG & - \\
\hline D25-12 & GGGACAGG & & ACAGAAGTCTTCTTTGGTAAAGGAACCAGACTCACAGTTGTAG & - \\
\hline D25-13 & GGGACAGGGGGC & GT & AACACAGAAGTCTTCTTTGGTAAAGGAACCAGACTCACAGTTGTAG & - \\
\hline D32-4 & GGGACAGGGGG & TGT & CACAGAAGTCTTCTTTGGTAAAGGAACCAGACTCACAGTTGTAG & + \\
\hline D32-6 & GGGACA & & CAGAAGTCTTCTTTGGTAAAGGAACCAGACTCACAGTTGTAG & - \\
\hline D32-8 & GGGACAGGGGG & TGT & CACAGAAGTCTTCTTTGGTAAAGGAACCAGACTCACAGTTGTAG & + \\
\hline D32-9 & GGGACAGGGGG & TTTG & CAAACACAGAAGTCTTCTTTGGTAAAGGAACCAGACTCACAGTTGTAG & - \\
\hline D32-10 & deleted*** & & GGTAAAGGAACCAGACTCACAGTTGTAG & \\
\hline D32-11 & GGGACAGGGGGC & GCCCCCTCCCA & CACAGAAGTCTTCTTTGGTAAAGGAACCAGACTCACAGTTGTAG & + \\
\hline D32-13 & deleted $^{\star \star \star \star}$ & GTAAGA & TTGTAG & \\
\hline D32-14 & GGGACA & & GAAGTCTTCTTTGGTAAAGGAACCAGACTCACAGTTGTAG & + \\
\hline D32-17 & GGGACAGGGG & ACCTTTG & CAAACACAGAAGTCTTCTTTGGTAAAGGAACCAGACTCACAGTTGTAG & - \\
\hline
\end{tabular}

Sequence analysis of coding joints in thymocytes from $\mathrm{p} 53^{-1}$ scid mice shows a diversity of $\mathrm{TCR}_{\beta}$ gene rearrangements. $\mathrm{D}_{\beta 1}-\mathrm{J}_{\beta 1.1}$ coding joints from thymocytes of one WT mouse and two $\mathrm{p} 53^{-1-}$ scid mice was amplified by PCR and subcloned into the pT7blue vector. Three individual WT clones were analyzed and the sequences are shown (W1, W2, and W5). A total of 15 clones from the two double mutant animals were sequenced. Only two of the fifteen clones showed the same sequence at the joint (D32-4 and D32-8). All of the clones contained an intact $5^{\prime}$ nonanucleotide, 12 nucleotide (nt) spacer and heptanucleotide signal sequence (SS) except where indicated. The recombination signal sequence (RSS) $3^{\prime}$ of D and $5^{\prime}$ of $J$ is not present in any double mutant clone. ( $\left.* *\right) 6$ bases of the $12 \mathrm{nt}$ spacer and the heptanucleotide SS are also deleted. $(\star \star \star)$ All of the D region except the 5 ' nonamer sequence is deleted. $(\star \star \star \star)$ D coding region deleted. $5^{\prime}$ RSS and spacer still present. 
progress to the $\mathrm{CD} 4{ }^{+} \mathrm{CD} 8{ }^{+}$stage despite their lack of TCR $\beta$ expression.

The scid mutation and loss of p53 cooperate in lymphomagenesis

Elimination of p53 function in the scid mutant resulted in the development of lymphoma with strikingly early onset. Lymphoma presenting in lymph nodes, spleen, bone marrow, and/or thymus was apparent in $>70 \%$ of the C57BL/6-129/Sv-C.B-17 double mutant mice that had to be sacrificed because of poor health $(n=42)$. In the C57BL/6-129/Sv-C.B-17 cohort, p53-1- scid mice with lymphoma were sacrificed on average at 10 weeks, compared with the $\mathrm{p} 53^{-1-} \mathrm{scid}{ }^{+1-}$ mice that had to be sacrificed because of lymphoma at a mean age of 18 weeks (Fig. 2A). Similarly, the C57BL/6-C.B-17 p53-1- scid mice that developed lymphoma $(n=19)$ were sacrificed
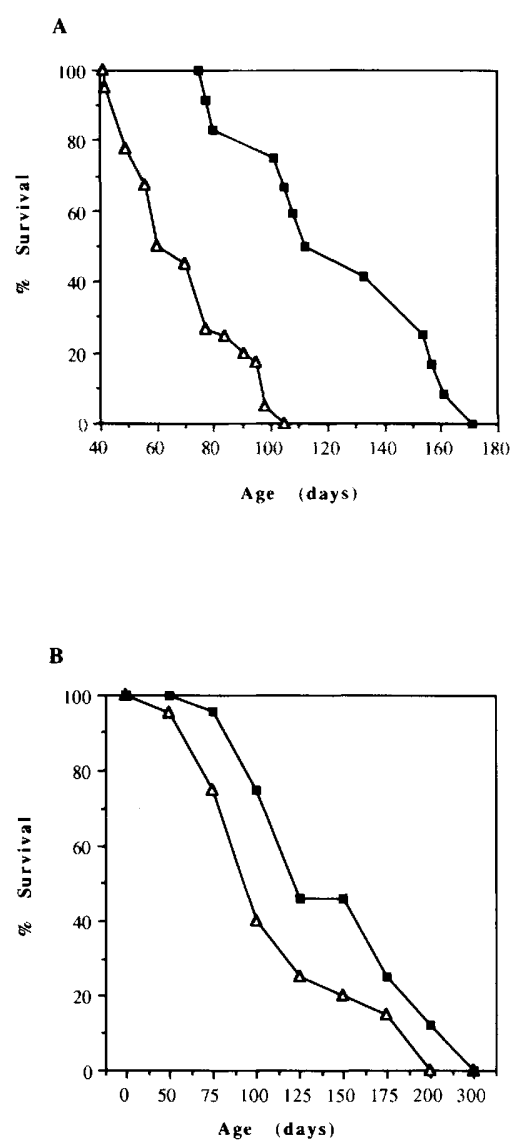

Figure 2. $\mathrm{p} 53^{-1-}$ scid mice develop lymphoma earlier than p53 ${ }^{-1-}$ mice. (A) C57BL/6-129/Sv-C.B-17 double mutant mice $(n=42)$ were sacrificed or died because of lymphoma between 42-105 days of age $(\triangle)$, whereas C57BL/6-129/Sv-C.B$17 \mathrm{p} 53^{-1-} \mathrm{scid}^{+1-}$ mice $(n=13)$ were sacrificed or died because of lymphoma between 77 and 171 days of age $(\mathbf{D})$. (B) C57BL/ 6-C.B-17 double mutant mice $(n=19)$ were sacrificed or died because of thymic lymphoma at 50-200 days of age $(\triangle)$. C57BL/

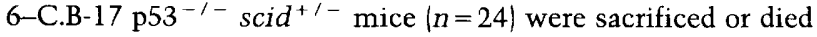
because of lymphoma at 75-300 days of age (ם). on average at 14 weeks, whereas the $\mathrm{p} 53^{-1-}$ controls with lymphoma were sacrificed on average at 19 weeks (Fig. 2B). Only one out of nine p53 $3^{+1+}$ scid mice $(11 \%)$ developed lymphoma by 30 weeks (data not shown), consistent with previous reports (Bosma and Carroll 1991). Homozygous mutation of the scid locus also accelerated lymphomagenesis in $\mathrm{p}^{+1-}$ heterozygous mice; in both cohorts $30 \%-40 \%$ of $553^{+1-}$ scid mice had developed lymphoma by 27 weeks compared with $<5 \%$ in control p53 ${ }^{+1-}$ mice (Jacks et al. 1994; data not shown). In summary, these results demonstrate that loss of p53 and a defect in DNA repair can cooperate in lymphomagenesis.

\section{p53-1- scid mice develop T-and B-cell lymphoma}

Immunofluorescence staining and flow cytometric analysis of tumor cells from lymph nodes of moribund double mutant animals revealed that some were of $\mathrm{T}$-cell and others of B-cell origin (Fig. 3). The T-cell tumors were $\mathrm{CD} 4{ }^{+} \mathrm{CD} 8^{+} \mathrm{B} 220^{-}$(Fig. 3c; Table 3) and the B-cell tumors were $\mathrm{CD} 4{ }^{-} \mathrm{CD} 8^{-} \mathrm{B} 220^{+}$(Fig. 3d; Table 3). All of the B-cell tumors from double mutant mice lacked surface IgM (Fig. 3d) and $\mathrm{TCR}_{\alpha \beta}, \mathrm{TCR}_{\gamma \delta}, \mathrm{CD} 3 \epsilon$ (not shown), as expected given the scid mutant background. Table 3 shows a more detailed characterization of five double mutant lymphoma cell lines derived from tumors that had presented in both the thymus and the lymph nodes. The presence of CD19, CD22, B220, and class II major histocompatiblity complex ( $\mathrm{MHCl}$, and the absence of CD21 and CD23 on the cell surface indicated that the B-cell lymphomas had originated from pre-B cells.

Immunohistochemical analysis using an antibody that recognizes B220 was consistent with the FACScan analysis data. All of the eight thymic lymphomas analyzed from the double mutant animals stained for B220/data not shown). Interestingly, approximately one-third of the tumors analyzed had patches of $\mathrm{B}^{2} 20^{+}$tumor cells and patches of ${\mathrm{B} 220^{-}}^{-}$tumor cells, whereas two-thirds was uniformly $\mathrm{B} 220^{+}$. Southern blot analyses of DNA from these tumors revealed that those showing incomplete B220 staining had undergone both TCR $D_{\beta 1}$ rearrangements and $I g D_{H}$ rearrangements, indicating that some of the tumors consisted of a mixture of $\mathrm{T}$ and $\mathrm{B}$ cells (data not shown). However, FACScan analysis of tumor cells from the lymph node of double mutant animals detected either T-cell or B-cell tumors, but not tumors of mixed cell type (Fig. 3). It is noteworthy that previous analysis of thymic lymphomas from C57BL/6-129/Sv p53-1mice showed that nearly all were $\mathrm{CD} 4{ }^{+} \mathrm{CD} 8^{+}$(Jacks et al. 1994; T. Jacks, A. Strasser, and A.W. Harris, unpubl.). However, in the C57BL/6-C.B-17 genetic background, 2 of 15 lymphomas analyzed were of B lineage origin (Fig. 3; data not shown).

scid cells induce p53 protein expression and arrest in $G_{1}$ following ionizing radiation

It has been suggested that the DNA-PK complex that includes the protein encoded by the scid locus is re- 

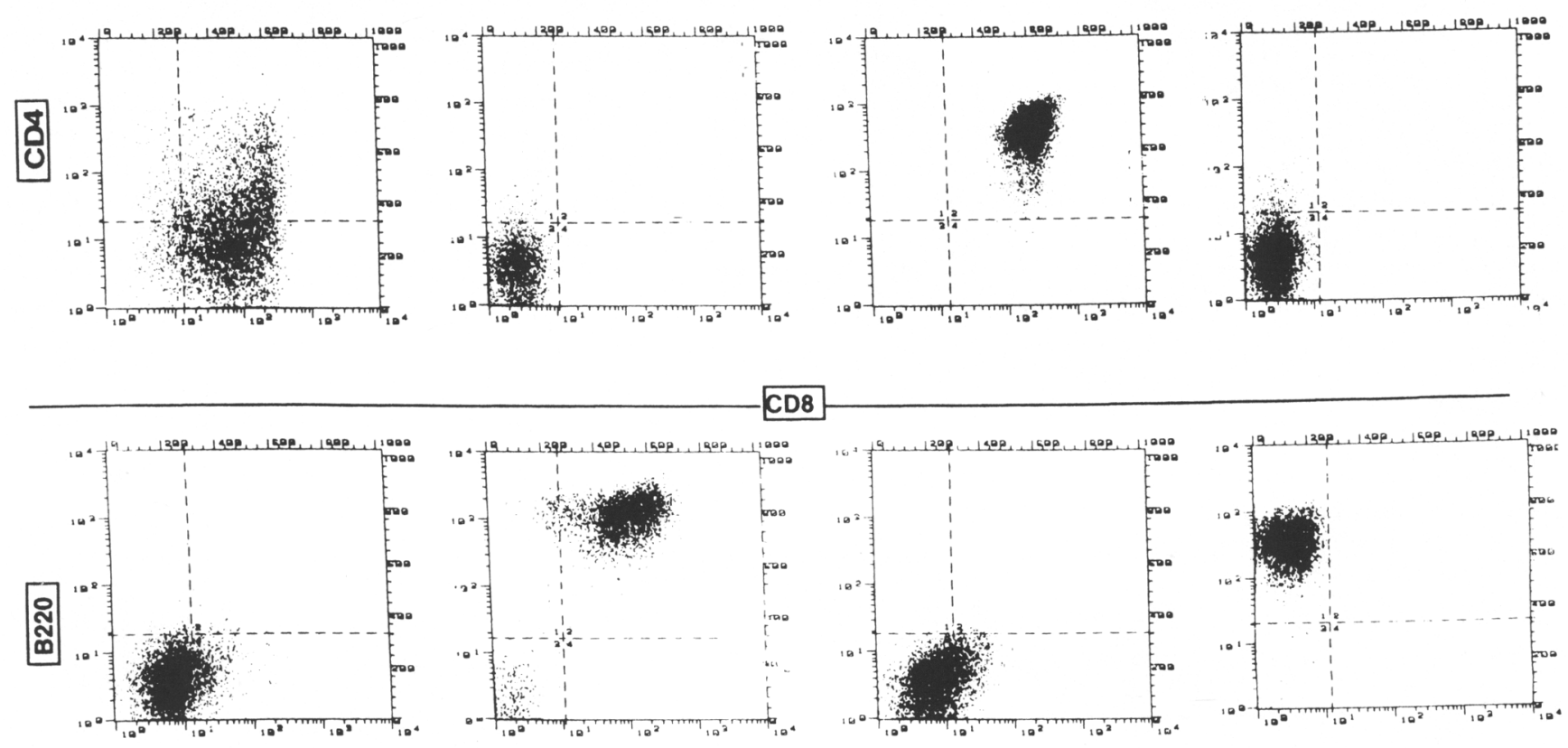

a

b

d

Figure 3. FACScan analysis of two p53 tumors and two p53 $1-$ scid tumors demonstrate both T-cell and B-cell lymphomas. Tumor cells from the lymph nodes of sacrificed C57BL/6-C.B-17 mice were isolated and analyzed by immunofluorescence staining and flow cytometry. Panel $a$ shows a $\mathrm{CD} 4^{+} \mathrm{CD} 8^{+} \mathrm{B} 220^{-} \mathrm{IgM}^{-} \mathrm{T}$-cell tumor from a p53 ${ }^{-1-}$ mouse; panel $b$ shows a $\mathrm{CD} 4^{-} \mathrm{CD} 8^{-} \mathrm{B} 220^{+} \mathrm{IgM}^{+} \mathrm{B}$-cell tumor from a p53 ${ }^{-1}$ mouse; panel $c$ shows a CD4 ${ }^{+} \mathrm{CD} 8^{+} \mathrm{B} 220^{-} \mathrm{IgM}^{-} \mathrm{T}_{\text {-cell }}$ tumor from a p53 $3^{-1-}$ scid mouse; panel $d$ shows a CD4 ${ }^{-} \mathrm{CD} 8^{-} \mathrm{B} 220^{+} \mathrm{IgM}^{-}$B-cell tumor from a $\mathrm{p} 53^{-1-}$ scid mouse.

quired to activate p53 in response to DNA damage /Gottlieb and Jackson 1994). However, the data described above show that the scid and $p 53$ mutations can cooperate in lymphomagenesis and that loss of p53 in a scid mutant background results in partial rescue of thymocyte development, suggesting that these gene products might be able to act independently in the cellular response to DNA damage. To examine directly if the scid locus encoded protein, DNA protein kinase (DNA-PKcs), is required to induce or activate p53 in response to DNA damage, we tested whether mutant scid cells could respond to ionizing radiation by inducing $\mathrm{p} 53$ protein expression and arresting in the $G_{1}$ phase of the cell cycle.

Wild-type, $\mathrm{p} 53^{-1-}$, and scid thymocytes were exposed to $6 \mathrm{~Gy}$ of ionizing radiation, and cell lysates were made $4 \mathrm{hr}$ following treatment. As shown in Figure 4, immunoblot analysis demonstrated that following DNA damage the p53 protein concentration is increased in scid thymocytes to levels comparable with those seen in normal cells. Furthermore, untreated scid thymocytes had higher levels of p53 protein than untreated wild-type thymocytes, suggesting that in scid thymocytes with defective DNA, p53 may be induced constitutively (Fig. 4; see below).

Mouse embryo fibroblasts (MEFs) derived from 13.5day-old embryos were used to determine whether the p53-mediated $\mathrm{G}_{1}$-arrest response following DNA damage was active in scid cells (Fig. 5). Wild-type, $\mathrm{p}^{-1-}$, and three different scid fibroblast lines were exposed to $6 \mathrm{~Gy}$ of ionizing radiation and incubated at $37^{\circ} \mathrm{C}$ for $12 \mathrm{hr}$ before pulse-labeling with the thymidine analogue $\mathrm{BrdU}$ for 4 hr (described in Kastan et al. 1991). The cells were fixed and stained with the DNA intercalating dye propidium iodide and a fluorescent anti-BrdU antibody and analyzed by flow cytometry (Fig. 5A). This experiment revealed that following irradiation, scid fibroblasts arrested in $G_{1}$ to the same extent as wild-type fibroblasts, as indicated by an absence of cells entering $\mathrm{S}$ phase (Fig. 5B). As reported previously, p53 $3^{-1-}$ cells did not arrest efficiently in $G_{1}$ (Kastan et al. 1992). Interestingly, although the $G_{1}$ arrest in scid fibroblasts was similar to that in wild-type cells, the $G_{2}$ arrest was more pronounced in scid cells. This result is consistent with earlier studies (Weibezahn et al. 1985) and suggests a possible role for DNA-PKcs in regulating the exit from $G_{2}$ arrest following DNA damage.

There have been several recent reports that $\mathrm{p} 53$ has a role in the $\mathrm{G}_{2} / \mathrm{M}$ arrest following DNA damage (Guillouf et al. 1995; Agarwal et al. 1995; Powell et al. 1995). To determine if the more pronounced $\mathrm{G}_{2}$ arrest associated with the scid mutation is dependent on p53, we performed the BrdU-labeling experiment described above on 
Table 3. Surface marker expression in $p 53^{-1-}$ scid lymphoma cell lines

\begin{tabular}{|c|c|c|c|c|c|}
\hline $\begin{array}{l}\text { Cell } \\
\text { surface } \\
\text { marker }\end{array}$ & $\mathrm{B} 80$ & B157 & $\mathrm{C} 8$ & $\mathrm{~B} 40$ & B 105 \\
\hline B220 & + & + & + & + & - \\
\hline CD25 & + & + & + & + & - \\
\hline CD19 & + & + & $+($ low $)$ & $+($ low $)$ & - \\
\hline class II MHC & + & $+($ low $)$ & + & + & - \\
\hline CD21 & - & - & - & - & - \\
\hline CD22 & + & + & + & + & - \\
\hline CD23 & - & - & - & - & - \\
\hline BP-1 & - & - & - & - & - \\
\hline PB76 & + & $+($ low $)$ & + & $+($ low $)$ & + \\
\hline HSA & + & + & + & + & + \\
\hline ThB & + & + & + & + & $+1-$ \\
\hline AA- 4 & + & + & $+($ low $\rangle$ & $+($ low $)$ & - \\
\hline $\mathrm{CD} 4$ & - & - & - & - & + \\
\hline CD8 & - & - & - & - & + \\
\hline Thy-1 & - & - & - & - & + \\
\hline TCR $\beta$ & - & - & - & - & - \\
\hline $\mathrm{CD} 43$ & - & - & - & - & - \\
\hline Gr-1 & - & - & - & - & - \\
\hline Mac-1 & - & - & - & - & - \\
\hline Ter-119 & - & - & - & - & - \\
\hline $\mathrm{B} / \mathrm{T}$ cell origin & pre-B & pre-B & pre-B & pre-B & pre- $T$ \\
\hline
\end{tabular}

Immunofluorescence staining and flow cytometric analysis of cell lines derived from lymphomas of C57BL/6-C.B-17 $\mathrm{p} 53^{-1-}$ scid mice demonstrates that the $\mathrm{B} 220^{+}$tumor cells are pre-B cell in origin, and the $\mathrm{CD} 4{ }^{+} \mathrm{CD} 8{ }^{+}$tumor cells are pre- $\mathrm{T}$ cell in origin.

fibroblasts derived from $\mathrm{p} 53^{-1-}$ scid mice. Figure 5, C and $\mathrm{D}$, shows that $\mathrm{p} 53^{-1}-$ scid cells, as expected, did not arrest efficiently in $G_{1}$ following exposure to ionizing radiation, but were able to arrest in $G_{2}$ to the same extent as scid cells. Therefore, p53 function is not required for the $G_{2}$ arrest seen after irradiation of scid fibroblasts.

scid thymocytes undergo apoptosis in response to DNA damage

The experiments described above show that DNA-PKcs is not required to induce p53 protein expression or activate $\mathrm{p} 53$ for its role in cell cycle arrest. To examine if DNA-PKcs is required to activate p53-dependent apoptosis, we compared the ability of irradiated scid thymocytes to undergo programmed cell death with that of irradiated wild-type thymocytes. Immature $\mathrm{CD} 4^{-} \mathrm{CD} 8^{-}$ $\mathrm{CD} 3{ }^{-} \mathrm{CD} 25^{+} \mathrm{CD} 44^{-}(\mathrm{DN})$ were isolated from normal $(\mathrm{Balb} / \mathrm{c})$, scid, and $\mathrm{p}^{-1-}$ mice (see Materials and methods) and either left untreated or $\gamma$-irradiated with 250 , 500,750 , or 1000 rads. Viability was determined for up to $48 \mathrm{hr}$ following treatment. Figure 6B shows the viability of thymocytes of each genotype at $6 \mathrm{hr}$ following treatment. Both scid and normal DN thymocytes died efficiently after exposure to 250 rads, whereas $553^{-1-} \mathrm{DN}$ thymocytes were highly resistant to radiation-induced death, even up to 1000 rads. However, $\mathrm{p} 53^{-1-}$ thymo- cytes died by $48 \mathrm{hr}$ following exposure to 250 rads (Fig. $6 \mathrm{Cl}$. Untreated thymocytes from scid mice were also highly susceptible to death in tissue culture (Fig. 6A), suggesting that these cells may be fragile because of their intrinsic DNA damage. In sum, these data demonstrate that the scid gene product, DNA-PKcs, is not required to induce or activate the $\mathrm{p} 53$ protein in response to DNA damage. Together, these data strongly suggest that the two genes function in distinct DNA damage control pathways.

\section{Discussion}

Although it is known that p53 induces cell cycle arrest or apoptosis in response to ionizing radiation, the signals that activate p53 and the mechanism of the cellular response to increased levels of p53 are still largely unknown. We and others have shown that treatment with agents that induce double-strand DNA breaks results in the induction and/or activation of p53 (Clarke et al. 1993; Lowe et al. 1993; Ziegler et al. 1994), suggesting that it is the broken DNA ends that act as an activation signal. The scid locus encoded protein, DNA-PKcs, is involved in a DNA damage control pathway, and is essential for proper joining of the ends of antigen receptor genes during the process of $V(D) J$ rearrangement in developing lymphocytes. Therefore, scid lymphocytes are an excellent source of cells with prevalent double-strand DNA breaks. By introducing a p53-null allele into mutant scid mice we were able to study the response of p53 to double strand DNA breaks in a physiological setting in vivo.

Our results indicate that eliminating p53 function promotes survival, proliferation, and differentiation of defective scid thymocytes beyond the $\mathrm{CD} 4^{-} \mathrm{CD} 8^{-}$ $\mathrm{CD} 25^{+} \mathrm{CD} 44^{-}$checkpoint to the $\mathrm{CD} 4^{+} \mathrm{CD} 8^{+}(\mathrm{DP})$ stage despite the absence of functional TCR $\beta$ surface expression. Thymi from $\mathrm{p} 53^{-1-}$ scid mice are at least twice the size of thymi from $\mathrm{p} 53^{+1-}$ scid or $\mathrm{p} 53^{+1+}$ scid littermates and in all cases, the excess cells were ac-

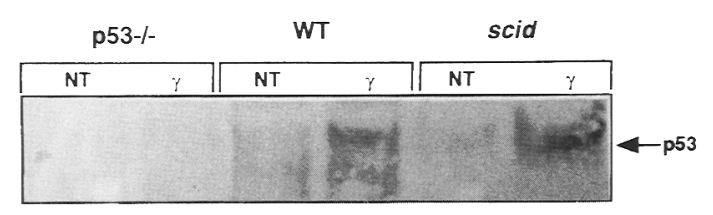

Figure 4. Immunoblot analysis of scid thymocyte lysates shows that p53 protein is induced strongly following ionizing radiation. Thymocytes from $\mathrm{p} 53^{-1-}$, wild-type (WT), and scid mice were irradiated with 6 Gy $(\gamma)$ or mock-irradiated (NT). Cells were incubated at $37^{\circ} \mathrm{C}$ for $4 \mathrm{hr}$ before extracting protein from the cells. Total protein $(100 \mu \mathrm{g})$ was loaded in each of the lanes, except WT lanes where $180 \mu \mathrm{g}$ of total protein was loaded. The proteins were separated by SDS-PAGE, transferred to PVDF membrane, stained with Ponceau $S$ to ensure equal loading between NT and $\gamma$ lanes, and immunoblotted with an antibody to p53. scid thymocytes strongly induced $\mathrm{p} 53$ protein expression following irradiation. 
Figure 5. The scid mutation does not impair radiation-induced $G_{1}$ cell-cycle arrest and the sciddependent delayed $G_{2}$ arrest is p53-independent. Control, p53-1- , scid, and $\mathrm{p} 53^{-1-}$ scid MEFs were irradiated with $6 \mathrm{~Gy}\langle\gamma|$ or mock-irradiated (NT). Twelve hours following treatment, the cells were pulse-labeled for $4 \mathrm{hr}$ with the thymidine analogue BrdU to mark DNA synthesizing cells and then stained with the DNA-intercalating dye propidium iodide and a FITC-conjugated antibody to BrdU. $(A)$ FACScan analysis of wildtype (WT) and three different scid fibroblast cell lines (scid-7, scid-9, and scid-10) show a $\mathrm{G}_{1}$ arrest following irradiation. $\mathrm{p} 53^{-1-}$ fibroblasts did not arrest in $G_{1} .(B)$ Bar graph of the percentage of cells in $S$ phase before and after irradiation. By this measure, scid cells were capable of $G_{1}$ arrest following radiation. (C) FACScan analysis of scid (p53 $3^{+1+}$ scid) and $\mathrm{p} 53^{-1-}$ scid MEFs shows that p53 $53^{-1-}$ scid fibroblasts arrest in $\mathrm{G}_{2}$ following irradiation. $\{D\}$ Bar graph of the percentage of cells in $G_{2}$ before and after irradiation. By this measure, scid and p53 scid cells can arrest in $\mathrm{G}_{2}$ following irradiation to the same extent.
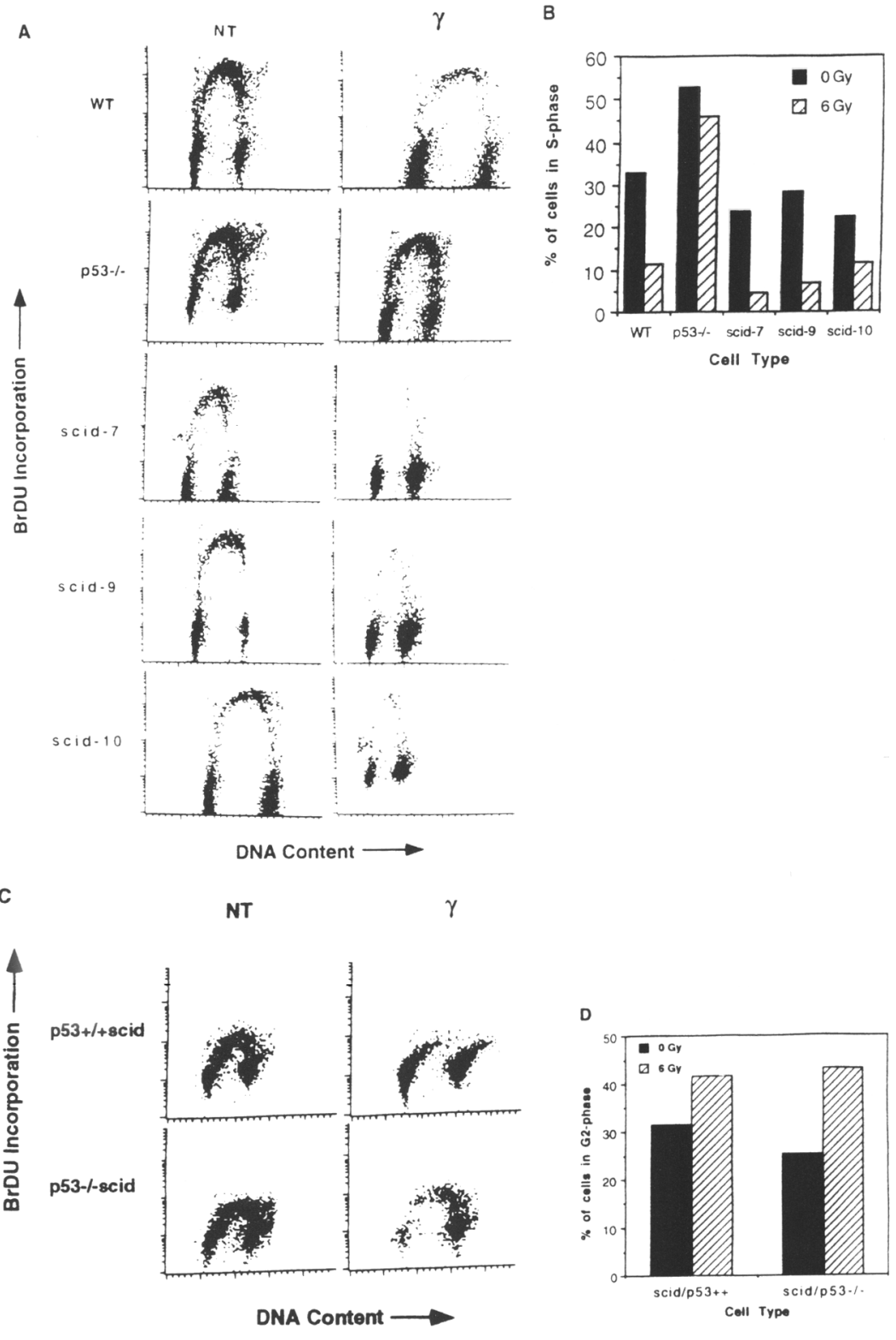

counted for by an increase in the $\mathrm{CD} 4{ }^{+} \mathrm{CD} 8{ }^{+}$population. Sequence analysis of the TCR $D_{\beta}-J_{\beta}$ joints demonstrated that the double mutant thymocytes were polyclonal and therefore resulted from developmental rescue rather than from the outgrowth of a single transformed clone. These data suggest that the unjoined DNA ends in scid thymocytes activate one or several p53-dependent pathways to induce growth arrest and/or apoptosis that results in the elimination of a large percentage of these defective cells. It is unclear whether it is the loss of p53dependent cell cycle arrest, apoptosis, or a combination of both that produces this phenotype in $\mathrm{p} 53^{-1-}$ scid thymocytes. Overexpression of the physiological cell death inhibitor $\mathrm{Bcl}-2$ antagonizes p53-mediated apoptosis in all cell types tested so far (Wang et al. 1993; Chiou et al. 1994; Strasser et al. 1994b) but has no detectable influence on in vivo survival and differentiation of scid $\mathrm{T}$ cells. It is therefore possible that loss of function of the p53-dependent apoptotic pathway is insufficient to promote expansion and differentiation of scid thymocytes. However, $\mathrm{BCl}-2$ can inhibit p53-dependent apoptosis by inducing cell cycle arrest (Chiou et al. 1994) and this may explain why $\mathrm{Bcl}-2$ is unable to rescue T-cell development in scid mutant mice. The data are also consistent with a requirement for p53-mediated cell cycle arrest as a constituent of the checkpoint in $T$ lymphopoiesis that selects for productive $\mathrm{TCR}_{\beta}$ rearrangement. It is interesting to note that this checkpoint is preceded by the $\mathrm{CD} 4^{-} \mathrm{CD} 8^{-} \mathrm{CD} 25^{+} \mathrm{CD} 44^{-}$stage where all cells are quiescent and engaged in $T C R_{\beta}$ gene rearrangement and followed by the $\mathrm{CD} 4^{-} \mathrm{CD} 8^{-} \mathrm{CD} 25^{-} \mathrm{CD} 44^{-}$stage that is composed entirely of cells that are cycling rapidly under 
A

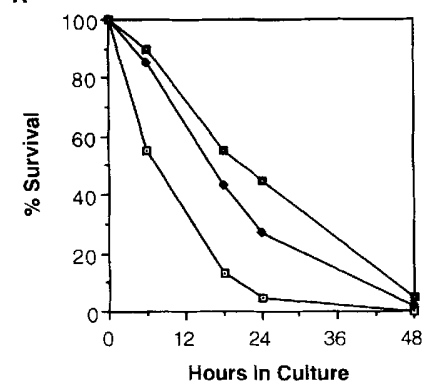

B

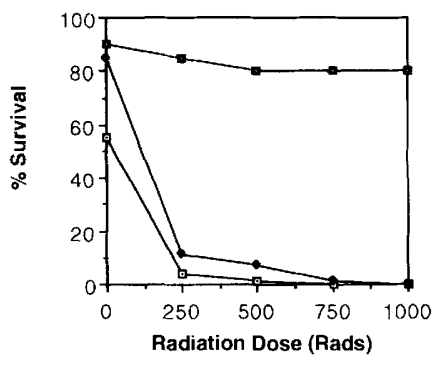

C

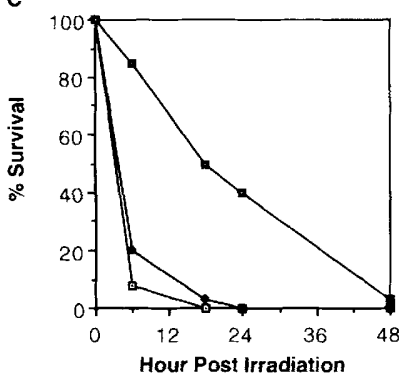

Figure 6. The scid mutation does not interfere with p53-dependent apoptosis in thymocytes. Survival of $\mathrm{CD}^{-} \mathrm{CD}^{-}$ $\mathrm{CD} 8{ }^{-} \mathrm{CD} 25^{+} \mathrm{CD} 44^{-}$thymocytes $(A)$ in tissue culture without radiation treatment; $|B| 6 \mathrm{hr}$ following treatment with 250 $1000 \mathrm{rads}$ ( $100 \mathrm{rads}=1 \mathrm{~Gy}) ;(C)$ up to $48 \mathrm{hr}$ following treatment with 250 rads. scid $(\square)$ and wild-type $(\downarrow)$ thymocytes are highly radiosensitive, whereas $\mathrm{p} 53^{-1-}(\mathbb{D})$ thymocytes are resistant.

the influence of a signal that requires TCR $\beta$, gp 33 , and the CD3 complex (Mombaerts et al. 1992; Godfrey and Zlotnick 1993; Godfrey et al. 1994; Fehling et al. 1995). Consistent with the idea that activation of this immature TCR complex generates a signal that promotes cellular proliferation and development is the discovery that injection of agonistic antibodies to $\mathrm{CD} 3$ or TCR $\beta$ into mutant scid or rag-1-deficient mice leads to a dramatic increase in thymocyte number and promotes their differentiation to $\mathrm{CD}^{+}{ }^{+} \mathrm{CD}^{+}{ }^{+}$stage (Shinkai et al. 1992; Levelt et al. 1993; Guidos et al. 1995). Interestingly, ionizing radiation itself can trigger a signal that promotes in vivo proliferation and differentiation of scid mutant thymocytes arrested at the $\mathrm{CD} 4{ }^{-} \mathrm{CD} 8^{-} \mathrm{CD} 25^{+} \mathrm{CD} 44^{-}$ stage (Danska et al. 1994; Zuñiga-Pflucker et al. 1994), perhaps by activating an alternative DNA damage repair pathway.

In contrast to the data from T-lineage cells, we did not observe rescue of B-cell development in $\mathrm{p} 53^{-1-}$ scid mice, suggesting that p53 is not essential for the check- point that selects for productive rearrangement of the $\operatorname{IgH}$ locus. The notion of differences in the molecular regulation of these corresponding checkpoints between $B$ and $\mathrm{T}$ cells is supported by the observations that radiation treatment rescues $\mathrm{T}-$, but not B-, cell development in scid mice (Danska et al. 1994; Zuñiga-Pflucker et al. 1994), whereas BCl-2 overexpression promotes B-, but not $\mathrm{T}$-, cell development in scid lymphocytes (Strasser et al. 1994a).

The data described above coupled with the high incidence of thymic lymphoma in $\mathrm{p} 53^{-1-}$ mice (Donehower et al. 1992) support a model in which a p53-dependent pathway leads to the elimination of cells with faulty or incomplete antigen receptor gene rearrangements that could produce oncogenic mutations by either activating proto-oncogenes or inactivating tumor supressor genes. This model predicts that $\mathrm{p} 53^{-1-}$ scid lymphocytes should be markedly predisposed to neoplastic transformation. Our data show that $\mathrm{p} 53^{-1-}$ scid animals develop lymphoma with an earlier onset than genetic background-matched $\mathrm{p} 53^{-1-}$ animals. However, the observed phenotype may also reflect the cooperation between a general defect in DNA repair and the absence of $\mathrm{p} 53$.

Although most of the tumors presented in the thymus and in other lymphoid organs, further characterization revealed unexpectedly that the majority $\langle 60-70 \%)$ of the $\mathrm{p} 53^{-1-}$ scid lymphomas were of pre-B-cell origin, and the rest of pre-T-cell origin (Fig. 3; Table 3). What might be the explanation for this surprising preponderance of pre-B lymphomas, given that only the $\mathrm{T}-$, but not the B-, cell lineage was affected noticeably in healthy double mutant animals (see Fig. 1B)? Genetic background may influence the type of lymphoma that is elicited by a particular mutation. Lymphomas in $\mathrm{p} 53^{-1-} \mathrm{C} 57 \mathrm{BL} / 6-129 /$ Sv mice are predominantly, if not exclusively, of $\mathrm{CD} 4{ }^{+} \mathrm{CD} 8{ }^{+}$T-cell origin (Jacks et al. 1994), whereas $\sim 13 \%$ of $\mathrm{p}^{-1}$ C.B-17-C57BL/6 mice developed B-cell lymphoma (e.g., see Fig. 3). Similarly, expression of a $\mathrm{v}-\mathrm{abl}$ transgene elicits predominantly $\mathrm{CD} 4{ }^{+} \mathrm{CD} 8{ }^{+}$thymomas on a C57BL/ 6 background but mostly pre-B lymphomas on a BALB/c background (Harris 1991). The stochastic onset of tumors in these double mutant animals suggests that one or several additional, oncogenic mutations are required for malignant transformation. Another explanation for the preponderance of pre-B over pre- $T$ lymphomas in $\mathrm{p} 53^{-1-}$ scid mice is the possibility that cooperating oncogenes are activated more easily in B cells, perhaps because they are situated in the vicinity of the $\operatorname{IgH}$ or $\operatorname{Ig} L$ loci and, therefore, are at increased risk of mutagenesis. Moreover, the block in B-cell differentiation at a stage characterized by high turnover could contribute to their neoplastic transformation, whereas, in contrast, pre-malignant $\mathrm{p} 53^{-1-}$ scid $\mathrm{T}$ cells can differentiate into short-lived postmitotic cortical $\mathrm{CD} 4{ }^{+} \mathrm{CD} 8{ }^{+}$ cells that may be at lower risk of sustaining further mutations. It will be interesting to define in further in vivo and in vitro experiments which oncogenes are able to synergize with the p53 and scid mutations in lymphomagenesis. 
The kinase complex that contains the scid locus encoded protein DNA-PKcs phosphorylates p53 in vitro, and it has been suggested that such phosphorylation occurs in vivo to induce or activate the p53 protein for its role in the cellular response to DNA damage /Gottlieb and Jackson 1994). Our data on lymphoma onset in double mutant mice indicate that the p53 and scid mutations cooperate in tumorigenesis, suggesting that they may function in distinct double-strand DNA damage response pathways. We demonstrated directly that the scid gene product is not required to induce or activate p53 in response to DNA damage by showing that radiation-induced p53-responsive pathways are active in scid cells. Mutant scid thymocytes were able to induce $\mathrm{p} 53$ protein expression following $\gamma$-radiation and the p53-mediated $\mathrm{G}_{1}$ arrest in fibroblasts was functional in scid fibroblasts. Furthermore, p53-dependent apoptosis occurred in scid DN thymocytes exposed to ionizing radiation, even at very low doses of radiation. It is interesting to speculate that the extreme sensitivity of scid thymocytes to radiation is attributable to a primed p53 DNA damage response pathway caused by the endogenous damaged DNA in these cells. All of these data argue strongly that p53 and DNA-PKcs are in different DNA damage repair pathways. Our results are consistent with a recent report showing that $\mathrm{p} 53$ is required for radiation-induced rescue of $V(D) I$ recombination in scid thymocytes (Bogue et al. 1996), perhaps because radiation activates a p53-dependent DNA damage repair pathway that allows $V(D) /$ rearrangement to proceed.

The function of p53 in the DNA damage response is clearly crucial to the proper functioning of many cell types. Humans afflicted with Li-Fraumeni syndrome or ataxia-telangiectasia lack normal p53 function and are highly predisposed to developing tumors, including lymphoma (Morrell et al. 1986; Hecht and Hecht 1990; Malkin 1993). Moreover, a p53 mutation dramatically sensitizes mice to radiation; irradiated p53-heterozygotes develop tumors, particularly lymphoma, with a reduced latency (Kemp et al. 1994). Our data suggest a role for p53 in sensing double-strand DNA ends caused, not only by exogenously introduced damaging agents such as radiation, but also by faulty antigen receptor gene rearrangement. Specifically, the loss of p53 leads to the survival of defective pre-T lymphocytes and can cooperate with mutations that affect antigen receptor gene rearrangement in lymphomagenesis. Further studies on the combinatorial effects of $p 53$ mutations associated with other mutations that affect DNA recombination and/or repair are therefore expected to increase our understanding of the physiological role of p53 in the cellular response to DNA damage and the checkpoint controls during lymphopoiesis.

\section{Materials and methods}

Generation of $p 53^{-1-}$ scid mice

Homozygous mutant $\mathrm{p} 53^{-1-}$ mice (C57BL/6-129/Sv) (Jacks et al. 1994) were bred with homozygous mutant C.B-17 scid mice from Taconic Laboratories (Germantown, NY) or the Walter and Eliza Hall Institute of Medical Research animal breeding facilities (Kew, Australia) to obtain $\mathrm{F}_{1} \mathrm{p} 53^{+1-} \mathrm{scid}^{+/-}$offspring. Double mutant animals were then generated by two

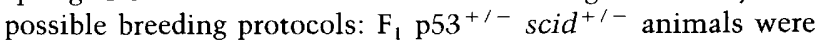
backcrossed to scid mice to fix the scid mutation and double mutant mice were created by intercrossing the p53+1- scid $\mathbf{F}_{2}$ animals. These were the mice on the C57BL/6-129/Sv-C.B-17 background. Alternatively $\mathrm{p} 53^{-1-}$ scid mice were generated by cross-breeding $\mathrm{F}_{1}$ animals; these were the mice on the C57BL/ 6-C.B-17 background. Homozygosity for the scid mutation was confirmed by FACS analysis of peripheral blood lymphocytes with antibodies against $\mathrm{B} 220$ and $\mathrm{CD} 3 \epsilon$, as described below. p53 status was determined by PCR analysis of tail or peripheral blood leukocyte DNA as described previously (Jacks et al. 1994). All crosses were carried out under specific pathogen free (SPF) conditions. Mice were placed on a sulfamethoxazole regimen to control Pneumocysitis carinii infection.

\section{Flow cytometry}

Flow cytometric analysis was performed using a FACScan (Becton Dickinson). FITC- or phycoerythrin-conjugated monoclonal antibodies directed against CD4, CD8, TCR $\alpha \beta$, TCR $\gamma \delta, \mathrm{B} 220$, and IgM, were obtained from Pharmingen. All other antibodies were prepared and used as described previously (Strasser et al. 1991). Monoclonal antibodies were labeled either with fluorescein isothiocyanate (FITC) or biotin and revealed with R-phycoerythrin (R-PE) streptavidin (Caltag).

Cell cycle analysis was performed using methods described previously (Kastan et al. 1991). Briefly, MEFs were derived from 13.5-day-old embryos and exposed to 0 or $6 \mathrm{~Gy}$ of ionizing radiation. The cells were incubated at $37^{\circ} \mathrm{C}$ for $12 \mathrm{hr}$, then labeled with bromodeoxyuridine $(\mathrm{BrdU})$ for $4 \mathrm{hr}$ at $37^{\circ} \mathrm{C}$. Cells were harvested, fixed, and stained with propidium iodide and a FITCconjugated anti-BrdU antibody (Boehringer Mannheim).

\section{Sequence analysis of $D_{\beta}-I_{\beta}$ joints}

DNA was extracted from the thymi of 5- to 6-week old C57BL/ 6-129/Sv-C.B-17 p53-1- scid mice. TCR $\mathrm{D}_{\beta}-\mathrm{J}_{\beta}$ joints were amplified by PCR using the following primers: $\left(D_{\beta}\right) 5^{\prime}-T_{T T T}-$ TA(T/C)/C/A $|A| T / A|G| G / C) T G T A A C A T T G T G-3^{\prime}, \quad\left(J_{\beta 1.2}\right)$ 5' AGTCCCAGACATGAGAGAGC-3'. The 500-bp band corresponding to the $D_{\beta 1}-J_{\beta 1.1}$ was purified, reamplified by PCR, and subcloned into the pT7blue vector (Novagen). DNA was extracted from individual colonies and sequenced using either the D $\beta$ primer or the universal U19 primer.

\section{Tumor analysis}

Animals that died or were sacrificed were subjected to necropsy. Tumor samples were removed and fixed in $10 \%$ neutral buffered formalin. Specimens were processed for histology, embedded in paraffin, sectioned at $6 \mu$ and stained with hematoxylin and eosin.

\section{Immunoblot analysis}

Thymocytes from wild-type, $\mathrm{p} 53^{-1-}$, and scid mice were exposed to 0 or $6 \mathrm{~Gy}$ of ionizing radiation from a ${ }^{137}$ Cesium source. Four hours following treatment, cells were resuspended in RIPA buffer $1300 \mathrm{~mm} \mathrm{NaCl}, 50 \mathrm{~mm}$ Tris at $\mathrm{pH} 7.2,1 \%$ sodum deoxycholate, $1 \%$ Triton $\mathrm{X}-100,0.1 \%$ SDS, $1 \mathrm{~mm}$ sodium pyro- 
phosphate, $1 \mathrm{mM}$ DTT, $1 \mu \mathrm{g} / \mathrm{ml}$ of aprotinin, $0.5 \mathrm{~mm}$ benzamidine, $1 \mu \mathrm{g} / \mathrm{ml}$ of pepstatin, and $0.5 \mathrm{~mm}$ PMSF), and pulse-sonicated. Extracts were incubated with 50 units of DNase I on ice for $30 \mathrm{~min}$ and cleared by centrifugation for $30 \mathrm{~min}$. Proteins were electrophoretically separated on a $12 \%$ SDS-PA gel and transferred to polyvinylidene difluoride (PVDF) (Westran; Schleicher \& Schuell). Protein was detected by incubation with an antibody that recognizes p53 (Ab-3; Oncogene Science), followed by incubation with chemiluminescent reagents (ECL, Amersham).

\section{Cell sorting and cell death analysis}

Cells were purified essentially as described (Godfrey et al. 1993) by staining isolated thymocytes with rat monoclonal antibodies to CD3, CD4, CD8, B220, Gr-1, Mac-1, and Ter119. Cells were then incubated with goat anti-rat immunoglobulin magnetic beads to deplete bound cells. The remainder were stained with Tricolor goat anti-rat immunoglobulin /Caltag) to stain the unwanted cells that were not depleted by the magnet. Next, the cells were stained with anti-CD25-PE (Caltag), biotinylated anti-CD44, and Texas red anti-Thy- 1 in the presence of $1 \%$ rat serum to prevent binding of the Tricolor anti-rat antibodies to rat anti-CD25,-CD44, or -Thy-1. Finally, the cells were stained with streptavidin-FITC (Caltag), in the presence of $1 \%$ rat serum, to reveal the biotinylated anti-CD44 antibody. Using the FACSstar Plus or a modified FACSII, $2 \times 10^{5}$ cells from each mouse were sorted. Cells were then resuspended in Dulbecco's modified Eagle medium (DMEM) supplemented with 10\% FCS, $50 \mu \mathrm{M} 2-\mathrm{ME}, 13 \mathrm{~mm}$ folic acid, and $250 \mathrm{mM}$ L-Asn at a densitiy of $2 \times 10^{5}$ cells $/ \mathrm{ml}$. Cells were left untreated or exposed to 250 , 500,750 , or 1000 rads of ionizing radiation from a ${ }^{137}$ Cesium source. Viability was determined after $6,18,24$, and $48 \mathrm{hr}$ by visual inspection using phase-contrast on an inverted microscope.

\section{Acknowledgments}

We thank Jianzhu Chen for many helpful discussions and for critical reading of the manuscript; Elizabeth Farrell for help in preparing the manuscript; $M$. Stanley for technical assistance; K. Patane for animal husbandry, and F. Battye for expert assistance with flow cytometry. A.S. was a Special Fellow of the Leukemia Society of America and received support from the National Health and Medical Research Council (Canberra). A.S. and A.W.H. received support from the U.S. National Cancer Institute. M.S. is supported by a grant from the National Institutes of Health, R01 HL48702. T.J. is an Assistant Investigator of the Howard Hughes Medical Institute.

The publication costs of this article were defrayed in part by payment of page charges. This article must therefore be hereby marked "advertisement" in accordance with 18 USC section 1734 solely to indicate this fact.

\section{References}

Agarwal, M.L., A. Agarwal, W.R. Taylor, and G.R. Stark. 1995. p53 controls both the G2/M and G1 cell cycle checkpoints and mediates reversible growth arrest in human fibroblasts. Proc. Natl. Acad. Sci. 92: 8493-8497.

Biedermann, K.A., J. Sun, A.J. Giaccia, L.M. Tosto, and J.M. Brown. 1991. scid mutation in mice confers hypersensitivity to ionizing radiation and a deficiency in DNA double-strand break repair. Proc. Natl. Acad. Sci. 88: 1394-1397.

Blunt, T., N.J. Finnie, G.E. Taccioli, G.C.M. Smith, J. Demengeot, T.M. Gottlieb, R. Mizuta, A.J. Varghese, F.W. Alt, P.A.
Jeggo, and S.P. Jackson. 1995. Defective DNA-dependent protein kinase activity is linked to V(D)) recombination and DNA repair defects associated with the murine scid mutation. Cell 80: 813-823.

Bogue, M.A., C. Zhu, E. Aguilar-Cordova, L.A. Donehower, and D.B. Roth. 1996. p53 is required for both radiation-induced differentiation and rescue of $V(D) /$ rearrangement in scid mouse thymocytes. Genes \& Dev. 10: 553-565.

Bosma, M.J. and A.M. Carroll. 1991. The scid mouse mutant: Definition, characterization, and potential uses. Annu. Rev. Immunol. 9: 323-344.

Bosma, G.C., R.P. Custer, and M.J. Bosma. 1983. A severe combined immunodeficiency mutation in the mouse. Nature 301: $527-530$.

Chiou, S.-K., L. Rao, and E. White. 1994. Bcl-2 blocks p53-dependent apoptosis. Mol. Cell. Biol. 14: 2556-2563.

Clarke, A.R., C.A. Purdie, D.J. Harrison, R.G. Morris, C.C. Bird, M.L. Hooper, and A.H. Wyllie. 1993. Thymocyte apoptosis induced by p53-dependent and independent pathways. $\mathrm{Na}$ ture 362: 849-852.

Danska, J.S., F. Pflumio, C.J. Williams, O. Huner, J.E. Dick, and C.J. Guidos. 1994. Rescue of T cell-specific V(D)J recombination in SCID mice by DNA-damaging agents. Science 266: $450-456$.

Donehower, L.A., M. Harvey, B.L. Slagle, M.J. McArthur, C.A. Montgomery, J.S. Butel, and A. Bradley. 1992. Mice deficient for p53 are developmentally normal but susceptible to spontaneous tumours. Nature 356: 215-221.

Fehling, H.J., A. Krotkova, C. Saint-Ruf, and H. Von Boehmer. 1995. Crucial role for the pre-T cell receptor alpha gene in development of $\alpha \beta$ but not $\gamma \delta$ T cells. Nature 375: 795-798.

Fulop, G.M. and R.A. Phillips. 1990. The scid mutation in mice causes a general defect in DNA repair. Nature 347: 479-482.

Godfrey, D.I. and A. Zlotnik. 1993. Control points in early T-cell development. Immunol. Today 14: 547-553.

Godfrey, D.I., I. Kennedy, T. Suda, and A. Zlotnik. 1993. A developmental pathway involving four phenotypically and functionally distinct subsets of CD3-CD4-CD8-triple-negative adult mouse thymocytes defined by CD44 and CD25 expression. I. Immunol. 150: 4244-4252.

Godfrey, D.I., J. Kennedy, P. Mombaerts, S. Tonegawa, and A. Zlotnik. 1994. Onset of TCR-beta gene rearrangement and role of TCR-beta expression during CD3-CD4-CD8 thymocyte differentiation. I. Immunol. 152: 4783-4792.

Gottlieb, T.M. and S.P. Jackson. 1994. Protein kinases and DNA damage. Trends Biol. Sci. 19: 500-503.

Guidos, C.J., C.J. Williams, G.E. Wu, C.J. Paige, and J.S. Danska. 1995. Development of CD4 + CD8 + thymocytes in RAGdeficient mice through a $\mathrm{T}$ cell receptor beta chain-independent pathway. I. Exp. Med.. 181: 1187-1195.

Guillouf, C., F. Rosselli, K. Krishnaraju, E. Moustacchi, B. Hoffman, and D.A. Liebermann. 1995. p53 involvement in control of G2 exit of the cell cycle: Role in DNA damage-induced apoptosis. Oncogene 10: 2263-2270.

Harris, A. 1991. Mechanisms of B cell neoplasia. In Conference on mechanisms of B cell neoplasia (ed. F. Melchers and P. Michael), pp. 367-374. Editiones Roche, Basel, Switzerland.

Hecht, F. and B.K. Hecht. 1990. Cancer in Ataxia-telangiectasia patients. Cancer Genet. Cytogenet. 46: 9-19.

Hollstein, M., D. Sidransky, B. Vogelstein, and C.C. Harris. 1991. p53 mutations in human cancers. Science 253: 49-53.

Jacks, T., L. Remington, B.O. Williams, E.M. Schmitt, S. Halachmi, R.T. Bronson, and R.A. Weinberg. 1994. Tumor spectrum analysis in p53-mutant mice. Curr. Biol. 4: 1-7.

Kastan, M., Q. Zhan, W.S. El-Deiry, F. Carrier, T. Jacks, W.V. Walsh, B.S. Plunkett, B. Vogelstein, and A.J. Fornace Jr. 1992. 
Nacht et al.

A mammalian cell cycle checkpoint pathway utilizing p53 and GADD45 is defective in ataxia-telangiectasia. Cell 71: $587-597$.

Kastan, M.B., O. Onyekwere, D. Sidransky, B. Vogelstein, and R.W. Craig. 1991. Participation of p53 protein in the cellular response to DNA damage. Cancer Res. 51: 6304-6311.

Kemp, C.J., T. Wheldon, and A. Balmain. 1994. p53-deficient mice are extremely susceptible to radiation-induced tumorigenesis. Nature Genet. 8: 66-69.

Kirchgessner, C.U., C.K. Patil, I.W. Evans, C.A. Cuomo, L.M. Fried, T. Carter, M.A. Oettinger, and J.M. Brown. 1995. DNA-dependent kinase (p350) as a candidate gene for the murine SCID defect. Science 267: 1178-1183.

Lane, D.P. 1993. A death in the life of p53. Nature 362: 786-787.

Lees-Miller, S.P., R. Godbout, D.W. Chan, M. Weinfeld, R.S. Day III, G.M. Barron, and J. Allalunis-Turner. 1995. Absence of p350 subunit of DNA-activated protein kinase from a radiosensitive human cell line. Science 267: 1183-1185.

Levelt, C.N., A. Ehrfeld, and K. Eichmann. 1993. Regulation of thymocyte development through CD3. I. Timepoint of ligation of CD3 $\epsilon$ determines clonal deletion or induction of developmental program. J. Exp. Med. 177: 707-716.

Levine, A.J., J. Momand, and C.A. Finlay. 1991. The p53 tumour suppressor gene. Nature 351: 453-456.

Lieber, M.R., J.E. Hesse, S. Lewis, G.C. Bosma, N. Rosenberg, K. Mizuuchi, M.J. Bosma, and M. Gellert. 1988. The defect in murine severe combined immune deficiency: Joining of signal sequences but not coding seqments in $\mathrm{V}(\mathrm{D}) \mathrm{I}$ recombination. Cell 55: 7-16.

Lowe, S.W., E.S. Schmitt, S.W. Smith, B.A. Osborne, and T. Jacks. 1993. p53 is required for radiation-induced apoptosis in mouse thymocytes. Nature 362: 847-849.

Malkin, D. 1993. p53 and the Li-Fraumeni syndrome. Cancer Genet. Cytogenet. 66: 83-92.

Mombaerts, P., A.R. Clarke, M.A. Rudnicki, J. Iacomini, S. Itohara, J.J. Lafaille, L. Wang, Y. Ichikawa, R. Jaenisch, M.L. Hooper, and S. Tonegawa. 1992. Mutations in T-cell antigen receptor genes $\alpha$ and $\beta$ block thymocyte development at different stages. Nature 360: 225-231.

Morrell, D., E. Cromartie, and M. Swift. 1986. Mortality and cancer incidence in 263 patients with ataxia-telangiectasia. I. Natl. Cancer Inst. 77: 89-92.

Powell, S.N., J.S. DeFrank, P. Connell, M. Eogan, F. Preffer, D. Dombkowski, W. Tang, and S. Friend. 1995. Differential sensitivity of $\mathrm{p} 53(-1)$ and $\mathrm{p} 53(+)$ cells to caffeine-induced radiosensitization and override of G2 delay. Cancer Res. 55: 1643-1648.

Rolink, A. and F. Melchers. 1991. Molecular and cellular origins of B lymphocyte diversity. Cell 66: 1081-1094.

Schuler, W., I.J. Weiler, A. Schuler, R.A. Phillips, N. Rosenberg, T.W. Mak, J.F. Kearney, R.P. Perry, and M.J. Bosma. 1986. Rearrangement of antigen receptor genes is defective in mice with severe combined immune deficiency. Cell 46: 963-972.

Shinkai, Y., G. Rathbun, K.P. Lam, E.M. Oltz, V. Stewart, M. Mendelsohn, J. Charron, M. Datta, F. Young, A.M. Stall, and F.W. Alt. 1992. RAG-2-deficient mice lack mature lymphocytes owing to inability to initiate V(D) rearrangement. Cell 68: $855-867$.

Strasser, A., A.W. Harris, and S. Cory. 1991. bcl-2 trangene inhibits $\mathrm{T}$ cell death and perturbs thymic self-censorship. Cell 67: 889-899.

Strasser, A., A.W. Harris, L.M. Corcoran, and S. Cory. 1994a. Bcl-2 expression promotes B- but not T-lymphoid development in scid mice. Nature 368: 457-460.

Strasser, A., A.W. Harris, T. Jacks, and S. Cory. 1994b. DNA damage can induce apoptosis in proliferating lymphoid cells via p53-independent mechanisms inhibitable by Bcl-2. Cell 79: 329-339.

Wang, Y., L. Szekely, I. Okan, G. Klein, and K.G. Wiman. 1993. Wild-type p53-triggered apoptosis is inhibited by bcl-2 in a v-myc-induced T cell lymphoma line. Oncogene 8: 34273431 .

Weaver, D.T. 1995. What to do at an end: DNA double-strandbreak repair. Trends Genet. 11: 388-392.

Weibezahn, K.F., H. Lohrer, and P. Herrlich. 1985. Doublestrand break repair and G2 block in Chinese hamster ovary cells and their radiosensitive mutants. Mutat. Res. 145: $177-183$.

Ziegler, A., A.S. Jonason, D.J. Leffell, J.A. Simon, H.W. Sharma, J. Limmelman, L. Remington, T. Jacks, and D.E. Brash. 1994. Sunburn and $\mathrm{p} 53$ in the onset of skin cancer. Nature 372: 773-776.

Zuniga-Pflucker, I.C., D. Jiang, P.L. Schwartzberg, and M.J. Lenardo. 1994. Sublethal $\gamma$-radiation induces differentiation of CD4 - /CD8 - into CD4 + /CD8 + thymocytes without $\mathrm{T}$ cell receptor $\beta$ rearrangement in recombinase activation gene 2-/-mice. I. Exp. Med. 180: 1517-1521. 


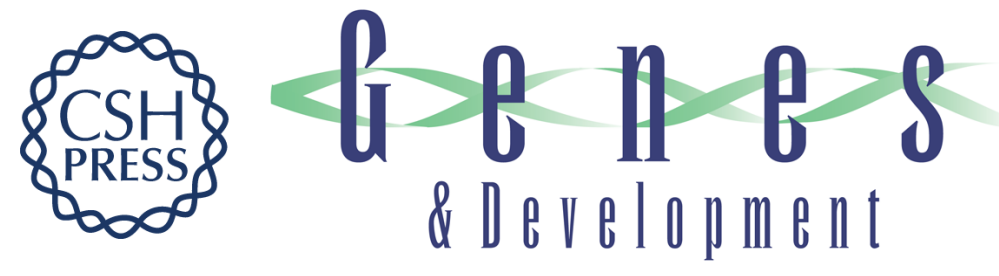

\section{Mutations in the p53 and SCID genes cooperate in tumorigenesis.}

M Nacht, A Strasser, Y R Chan, et al.

Genes Dev. 1996, 10:

Access the most recent version at doi:10.1101/gad.10.16.2055

References This article cites 46 articles, 15 of which can be accessed free at: http://genesdev.cshlp.org/content/10/16/2055.full.html\#ref-list-1

License

Email Alerting

Receive free email alerts when new articles cite this article - sign up in the box at the top Service right corner of the article or click here.

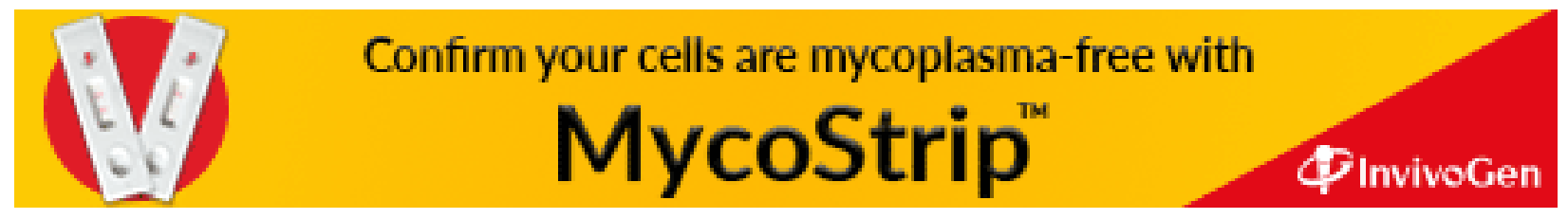

